\title{
DEVELOPMENT OF COOPERATION SKILLS DURING ACQUISITION PROCESS OF JAZZ SINGING
}

\section{SUMMARY}

Introduction. During jazz studies, a student develops not only the skill to play the chosen instrument or the vocal technique, but also participates at sessions of playing music in groups. To successfully incorporate in this creative process, theory-wise, practical and psychological readiness is needed, as well as cooperation skills.

Aim of the Study. To find possibilities to develop cooperation skills during acquisition process of jazz singing.

Materials and Methods. Analysis of pedagogical and psychological theory, pedagogical observation, analysis of artistic experience, questionnaires.

Results. Results of questionnaires have been summarised, possibilities to develop cooperation skills during acquisition process of jazz singing have been found.

Conclusions. It is necessary to develop contents of studies, drawing more attention to sessions of playing music in groups, purposefully preparing students for work in groups, taking into account individual readiness and gradualness.

Key words: musical pedagogy, jazz music, playing music in groups, cooperation skills

\section{INTRODUCTION}

Playing jazz involves creativity that besides other music genres stands out due to its spontaneous improvising character caused by group work and cooperation phenomenon at the specific moment. Without a definite concept on the set of needed skills, a student fails to evaluate group sessions in his study process and fails to develop himself as a participant of a group, thus failing to develop himself as a harmonious musician. Cooperation in this case is respecting of each musician's individuality and its accentuation. Fulfilling their own goals, students unite in group work with common goal of the group. By insufficient emphasis on the meaning of cooperation in playing jazz, we fail to provide the student with a clear concept of equal worth of musical and cooperation skills. Developed cooperation skills form the professionalism cornerstone of each high quality jazz musician.

\section{AIM OF THE STUDY}

To find possibilities to develop cooperation skills during acquisition process of jazz singing.

\section{MATERIALS AND METHODS}

To fully acknowledge the role of cooperation skills at playing jazz, the jazz specifics must be understood. Stressing the meaning of improvisation during playing music, cooperation in jazz does not take the form of observation that is merely expressed as participation or merging with the sound of orchestra or chorus, rather the cooperation. This is a set of skills that requires a special musical preparedness and psychological readiness. A jazz singer develops his vocal skills, improvisation skills, knowledge of music theory and styles, in order to use all this knowledge and skills at the moment of cooperation when playing jazz as a group. A jazz singer cannot perform individually 
(separate compositions in a programme can be an exception). The singer needs musicians for creation and presentation of joint music, thus not only musical skills and knowledge is necessary, but also social skills. All these skills make a precondition to a successful musical cooperation. If a student is not ready to cooperate musically or fails to acknowledge the sense of lessons, the work is not productive and fails to develop his individual jazz skills and cooperation skills.

Following tendencies of global jazz education, one has to observe that jazz pedagogues speak more and more about such values as mutual cooperation among students at playing music. A Dutch pedagogue, Chairman of the European Music Council and Executive Director of International Association of Schools of Jazz (IASJ) Wouter Turkenburg says that all are equal in jazz music. One may have a more developed instrument play or vocal technique than other players in the group, but that does not make the person automatically the best player or improviser. Mutual interaction is the main characteristic trait. Development of one's skills can help, but it would not be the crucial one. It is more important how student uses skills of technique in musical practice, and not their scope or distinction. Jazz will sound differently played by music students because they would have learnt how to play in a mutually effective, natural manner. They will be able to play irrespective of the chosen time and chosen person. As in daily relations with others, also in music they will be united with other musicians in an interactive, creative way. Creation of music will not be a strange activity anymore that has been separate from daily life, but it will become a completely normal phenomenon. When cooperation (good interplay) and improvisation takes the central place in musical education, future changes will be natural instead of extraordinary changes that are most needed and most necessary at the moment (Turkenburg, 2006).

Likewise the huge role of cooperation is stressed by American saxophonist, pedagogue and President of IASJ, David Liebmann: "Artistic development processes in jazz require huge enthusiasm, courage and discipline implemented through the skill to creatively express oneself. Creativity depends on the skill to cooperate. An artist always tries to be in harmony with his internal nature and to share this information through public" (Liebman, 2008, 25).

Verbal communication makes approximately only ten per cent of the communication that truly makes impression on the addressee (Denijs, 2002). At the moment of musical cooperation, it is therefore so very important to use body language (nods, hand gestures, eye contact) that would clearly express attitude and the aim of the activity.

In the era of technology progress and information abundance, a conflict raises between what we know and what we do. One of causes that disturb human communication is inability to listen to others (Doehring, 2002; Schiavetti, Metz, 2002).

The road to self-improvement is focussing on the conversation partner and trying to see his experience, position and attitude (Bišopa, 2002). Listening skills do not appear just like that. They become better if a student acknowledges their significance and can focus on this process.

At the beginning of studies, most of jazz singing students have not acquired experience at singing in a group, therefore mistakes that are related to lack of experience and bewilderment are observed.

Physical disassociation is one indicator of psychological disassociation. The less visual contact, the larger is the psychological distance (Renge, 2004).

These are the most often observed mistakes at the moment of singing jazz:

1) loss of natural contact (monotonous voice, inexpressive look, being unsure or arrogant);

2) monologue instead of a dialogue (I speak and listen to myself instead of talking to other musicians and the listener);

3) lack of gestures (causes the performance to become drab). 
Studies of jazz cooperation analysis show the special character of this process among other music genres. Study of cooperation is characterised by tendency to research by analysing individual musical development and influence of the development of cooperation skills on the personality (Kokotsaki, Hallam, 2007). Studies of cooperation skills during playing music often are social studies that draw most of the attention to the verbal expression instead of the non-verbal expression (Kieseritzky, Schwabe, 2005). When the maximum attention is focused on cooperation as musical act, one has to conclude that cooperation in jazz has specifics that divide it in two categories:

- Simpatic cooperation, when musicians work with their musical basis and improvise at the moment of joint playing of music without taking the risk of challenge of their musical individuality and group creativity. In music sense it is expressed in comparatively foreseeable, complementary phrases and responses ensuring musical unity without a risk of creativity, sharing one's musical experience. A form of relative disinterest can be observed here (few smiles, nods, energetic body movements). Musicians improvise but the improvisation in this case is based on jazz canons that are acquired during studies, but it lacks sufficient creative work. In case of simpatic uniformity, there is musical unity, but at the same time, there may be an internal musical conflict that is expressed in a diverse rhythm interpretation or adaptation of the weakest participant, thus preventing reaching the empathic level.

- Empathic cooperation, when musicians respond musically to each other in the atmosphere of challenge and risk that in turn deepens the basis of their knowledge. This uniformity is seen in expressing interest (smiles, joint nods, active body movements). In such special cases musicians go past supportive musical phrases and stimulate perception and creation of new ideas. This requires joint aesthetic judgement and unanimity of musicians (Seddon, 2005).

Pedagogical observations indicate that jazz students rarely reach empathic uniformity in their educational environment during studies, or the empathic uniformity is not reached simultaneously. This can be explained by lack of experience that depresses trust. Students are disturbed by observations and analysis during group sessions therefore undertaking of group risk is not stimulated.

Presence of other people can divert attention from the task to be completed and thus worsen the performance. Internal conflict arises in the person between attention towards other people and focus on the attention (Rengie, 2002).

To determine whether a particular jazz singing student has the necessary cooperation skills, how they are expressed and at what level, it is significant to develop criteria for establishing the degree of development of these skills.

Upon formation criteria and indicators of jazz singer's cooperation skills, a research by F. Seddon was used as basis (Seddon, 2005), as well as special features of a jazz singer prepared by $\mathrm{M}$. Weir were taken into account stressing a singer as the creator and reflector of the textual sense and artistic image of the song at the moment of cooperation (Weir, 2001).

At the moment of playing jazz, musicians have:

1) verbal communication;

2) non-verbal communication (eye contact, body language) that is expressed through musical interplay (Seddon, 2005).

This all together makes a musical performance whose quality depends on professional skills and scope of cooperation.

Criterion verbal communication or the information orally expressed during cooperation works as element of coordination and explanation. In sessions of jazz vocally-instrumental 
group, participants of the group are psychologically prepared for joint work. It is expressed as the students' interest, wish to become a part of the process and offer their ideas. Likewise an indicator of verbal communication is purposefulness, when aim is determined and acknowledged. A pedagogue substantiates choice of one or the other composition. Repertoire includes compositions of various jazz styles and rhythm pulsation so that students would acquire variety of styles and would be stimulated to increase their knowledge and train additionally. A goal of each session is set, likewise joint development is planned, means are searched to reach the goal. A student's activity at this stage should be characterised as understanding and accepting his individual aim and the common goal, as a positive feeling towards the expected joint work at staging the programme. The student's responsibility, serious attitude, respect should be included in psychological readiness that is expressed as regular preparation for the sessions, acquisition of the musical material at home, preparation of notes for instrumentalists and ability to explain one's opinion. Indicator of verbal communication - use of musical basis shows practical readiness for cooperation where the previous experience is evaluated, skills, knowledge and its use at the specific moment is discussed. A pedagogue and students speak about methods of style in compositions that will be used during performance. An important indicator of cooperation skills in a session of a vocally-instrumental group is evaluation of results, when the achieved results are analysed. The goal and the result must be compared thus evaluating the work. A student should advisably self-analyse and compare his development with the group progress. Such evaluation process should take place correctly and facilitate further intensive activity and setting of new goals.

Implementation of a jazz singer's activity in a group session is expressed also as non-verbal communication that is a transfer of any information and signals without any help of words, and this forms the second criterion of communication skills. The pedagogue encourages students to use all resources in order to achieve musical freedom. Training of will and undertaking of risk takes place, this forwards to achievement of empathic cooperation form. At first, non-verbal communication is expressed by body language - eye contact, gestures, as well as hand gestures that are understood by other participants in the group. An important skill of a jazz singer is a convincing language of gestures, indication of musical processes and in case of necessity - their leading.

A jazz singer's cooperation skills are shown by revelation of artistic image expressed by creation of atmosphere that corresponds to the image, encouraging the group during performance of the composition. In this case, use of text for revealing the artistic image of a song is one of means of artistic expression that reveal song contents and emotional attitude, but at the moment of performance it does not perform the function of mutual communication; the literary text is an element complementing the music. This explains placement of this indicator at criteria of nonverbal communication and here cannot be regarded as verbal communication because the text expressed by the singer does not provide instructions for formation of musical processes.

Indicator of communicative skills - listening skill should be regarded as one of efficiency conditions for cooperation of jazz musicians. The listening skill is revealed by adequate musical presence at the particular performance. This means to be "together with the group" all the time and to listen not only to oneself but also to all instruments separately and the joint musical sound. The next indicator - impulsive interaction forms the following link of efficient cooperation chain. This is a skill not only to hear the musical impulses of group participants but also to reply to them through improvisation. The highest cooperation productivity level is revealed by the final indicator - empathic creativity based on knowledge of jazz theory, skills and experience, and by creative 
experiments (using courage and originality) giving one's musical impulse. This indicator shows a student's creative skills to offer original, amazing musical ideas during group cooperation.

If the acquisition process of jazz singing is organised as cooperation, motivating students to cooperate and explaining the meaning of cooperation in jazz, coherence is formed - development of individual skills takes place during cooperation in group sessions, and cooperation skills are developed by individual jazz singing sessions.

\section{RESULTS}

There are possibilities offered to study jazz music also in master classes and camps. Not just students but also teachers form Latvia and foreign countries take part sharing experiences and establishing contacts for future cooperation. During the study, experience and opinions were shared with foreign pedagogues who worked at summer jazz camps during Saulkrasti Jazz Festival (from 2005 to 2009) and got acquainted with the level of jazz education of Latvian youth and evaluated their interest and enthusiasm during sessions. In order to get acquainted with the opinion of foreign pedagogues, an electronically survey was carried out where the pedagogues replied to questions on the advisable level of cooperation skills of a university graduate (bachelor's degree). The survey was based on the developed cooperation criteria and indicators and summarised in a questionnaire with the aim to find out the pedagogues' opinions. As the result pedagogues were evaluating the advisable level of cooperation skills (1- 10 points) which were the most important and necessary for university graduates (bachelor's degree) of jazz singing. Six foreign pedagogues took part at the research:

1. Janet Lawson - professor from the USA, New York (New School University),

2. Annette Griesriegl - lecturer from Austria, Graz (University of Music and Dramatic Arts),

3. Sheliyah Masry - pedagogue from France, Paris, manager of a gospel choir, specialist of vocal technique,

4. Tena Palmer - lecturer from Canada, Ottawa (Carleton University),

5. Cecil Verny - lecturer from Germany, Freiburg (Jazz and Rock School in Freiburg, State Conservatory in Trossingen),

6. Norbert Gottschalk - lecturer from Germany, Maastricht (Staatlichen Conservatorium fur Music in Maastricht).

Having summarised the data (see Picture 1), different opinions can be noticed about the advisable level of cooperation skills of a university graduate.

Picture 1. Foreign pedagogues' opinion about the advisable level of cooperation skills of university graduates
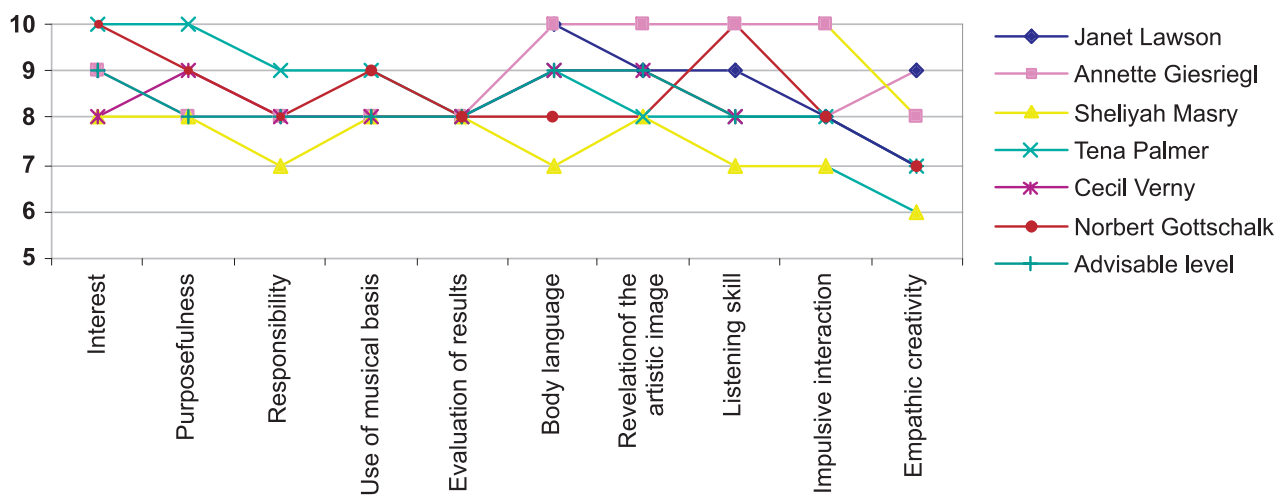
All respondents highly appreciate the role of interest during studies ( $8-10$ points).

Almost the same evaluation is reached for the advisable level of purposefulness $(8-10$ points), the majority slightly moves towards mark 8 . The advisable level of responsibility has been evaluated by the respondents within the scope of 7 to 9 points, where one respondent allows the level of responsibility to drop to mark 7. The advisable level of using the musical basis has united the respondents' opinions within the scope 8 to 9 points, and responses to necessity to evaluate results make the respondents having agreed to a joint evaluation of 8 points. There is a quite different opinion on necessity to manage body language during cooperation. This is shown by the responses between 7 and 10 points, but the indicator of revelation of the artistic image in the chart has united the opinions between 8 to 10 points. The final three indicators show the advisable level of artistic cooperation during musical cooperation. These opinions likewise provide a quite large amplitude - the advisable levels of listening skills and impulsive interaction have been evaluated in the range of 7 to 10 points, and the empathic creativity as the most complicated link in the chain of these three indicators has been evaluated between 6 and 9 points giving a leeway to further development of skills that according to the pedagogues continues for the whole life.

After summarising opinions of all the foreign pedagogues on the advisable level of cooperation skills of university graduates, a new chart is prepared (see Picture 2) that reveals the large significance of interest in studies (9 points).

Picture 2. Average of foreign pedagogues' opinion about the advisable level of cooperation skills of university graduates

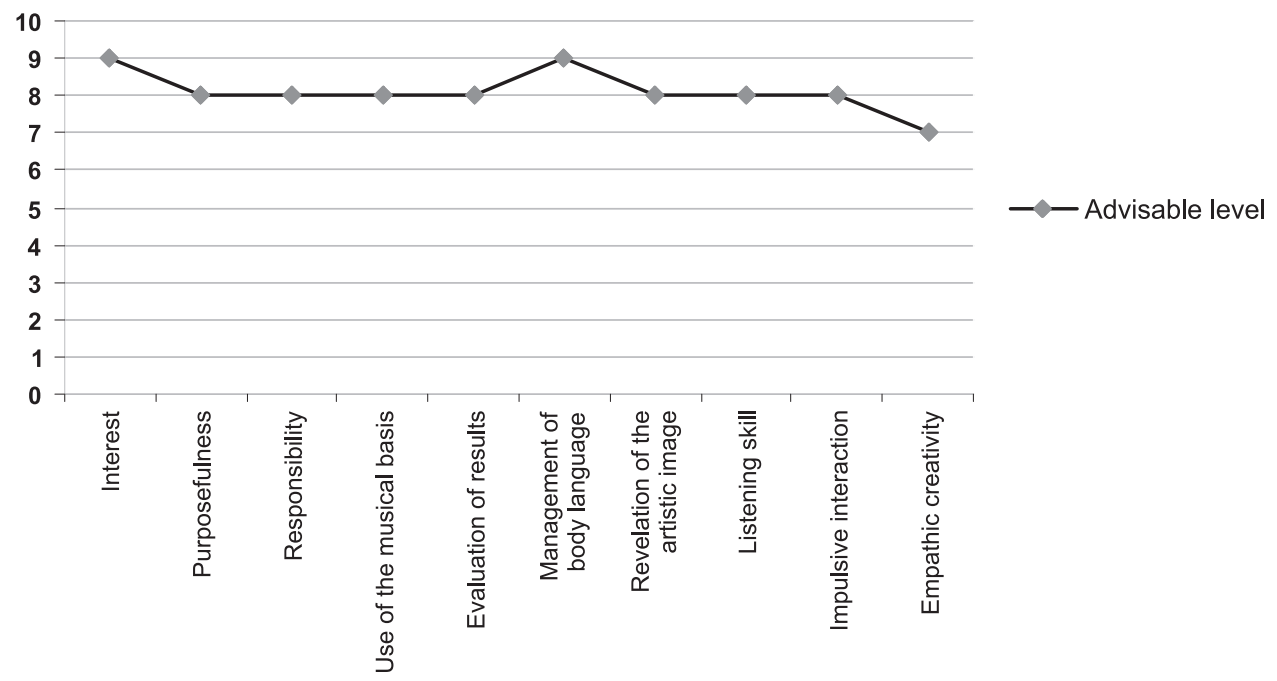

The advisable levels of purposefulness, responsibility and evaluation of results were given 8 points. For use of musical basis, an 8-point level of skills and knowledge is advisable. Level of managing body language has been evaluated higher -9 points, which can be explained by significance and necessity of these skills especially in a jazz singer' skill arsenal because these skills affect the stability of cooperation process (clear gestures and eye contact act as stabilizer of the cooperation process or in case of necessity - manager). Likewise highly evaluated are the advisable levels of musical processes - listening skills, impulsive interaction and empathic creativity. Slightly less - by 7 points - is the advisable level of empathic creativity evaluated. This can be explained by 
the pedagogues' objective observations of use of these skills at sessions. A musician develops his creative skills and expressions during his whole life, and a university graduate is at the beginning of his artistic road. Experience models the artist; therefore foreign pedagogues in this sphere have evaluated the advisable level of empathic creativity by 7 points.

\section{CONCLUSIONS}

The developed criteria have systematised cooperation skills in jazz singing and have helped students and pedagogues to improve their skills more purposefully and to see changes in the level of skills. Analysing students' performance during jazz studies and observing the changes in levels of their cooperation skills as well as taking into account the results of questionnaires, the following recommendations were developed:

1. During the study process it is advisable to create circumstances for students' development, to make them interested in new musical challenges, offers, projects, and competitions that would keep the students interested and facilitate their improvement.

2. It is advisable to encourage the student to continue setting new tasks in order to develop his professionalism, to encourage mutual cooperation to reach the goals.

3. It is advisable to create circumstances for an interesting and fascinating work during sessions, making students interested in acquisition of a new style, to offer possibilities of creative work in sessions, forming of untraditional arrangements.

4. It is advisable to encourage the student to develop comprehensively, to search ever new means of expression, styles. Observations show the students' great interest in new jazz trends and wish to approach them; this in turn extends the students' musical basis. A group session is a suitable place for new musical searches and expressions.

5. Evaluation of results during sessions should be organised as a regular, self-evident, organic process that does not require encouragement and prompting, but it brings toward development and particular tasks in the future sessions.

6. It is advisable to draw special attention to the work with skills of body language management. According to the foreign pedagogues, this was assessed as a skill with the advisable level within the scope of cooperation skills of a jazz singer in the amount of 9 points. This proves the high significance of this skill in the professionalism of a jazz singer.

7. It is advisable to regularly develop the skills to reveal the artistic image that in turn would enrich the language of gestures and improve cooperation in the group.

8. Skill of impulsive interaction reveals the student's ability to react spontaneously towards the musical ideas of group members, but this skill should be developed in a new and higher level enriching one's musical basis.

9. Skill of empathic creativity includes many skills and knowledge whose sum forms the foundation for bright creative manifestations and requires musical maturity. It is advisable to gradually train using the skills; this is expressed by regular passing of musical challenges.

\section{REFERENCES}

1. Bišopa, S. (2002) Attīsti savu pašpārliecību [Develop Your Confidence]. Rīga: Pētergailis, 107 lpp. (in Latvian).

2. Denijs, R. (2002) Prasme sazināties un uzstāties [Skill to Contact and Perform]. Rīga: Jāņa Rozes apgāds, 124 lpp. (in Latvian). 
3. Doehring, D. G. (2002) Research Strategies in Human Communication Disorders. $3^{\text {rd }}$ edition. Texas: An International Publisher Proed, 253 p.

4. Kieseritzky, H., Schwabe, M. (2005) Gruppenimprovisation als musikalische Basisarbeit [Group Improvisation as Musical Base Work]. In: Ensemblespiel und Klassenmusizieren in Schule und Musikschule: ein Handbuch für die Praxis [Playing Music in a Group and Class at School and Music School: Handbook for Practice]. Rudolf-Dieter Kraemer, Wolfgang Rudiger (Hrg.), 2. unveränderte Auflage. Augsburg: Wißner, S. 155-175 (in German).

5. Kokotsaki, D., Hallam, S. (2007) Higher Education Music Students' Perceptions of the Benefits of Participative Music Making. Music Education Research, Vol. 9, No. 1, p. 93-109.

6. Liebman, D. (2008) Reflection on Artistic Process. The Note. Part One, Winter/Spring, East Stroudsburg University Press, p. 24-25.

7. Reņge, V. (2004) Savstarpējo attiecību psiholoğija [Psychology of Mutual Relations]. Rīga: Zvaigzne ABC, 117 lpp. (in Latvian).

8. Reņǵe, V. (2002) Sociālā psihologija [Social Psychology]. Rīga: Zvaigzne ABC, 180 lpp. (in Latvian).

9. Schiavetti, N., Metz, D. E. (2002) Evaluating Research in Communicative Disorders. $4^{\text {th }}$ edition. Boston: A Pearson Education Company, $447 \mathrm{p}$.

10. Seddon, A. (2005) Modes of Communication during Jazz Improvisation. B. J. Music Ed. Cambridge University Press, p. 47-61.

11. Turkenburg, W. (2006) The Future of Music. Improvisation. Sounds in Europe. Issue No 2, Winter 2006-2007, p. 17-18.

12. Weir, M. (2001) Vocal Improvisation. New York: Advance Music, 231 p.

Lecturer, doctoral student Inga Bērzin̦a

Riga Teacher Training and Educational Management Academy

Address: Imantas 7. līnija 1, Rīga, LV-1083

Phone: +371 26542399

E-mail: inga.berzina@rpiva.lv

Prof. Dr. paed. Māra Marnauza

Riga Teacher Training and Educational Management Academy

Address: Imantas 7. linija 1, Rīga, LV-1083

Phone: +371 29461145

E-mail:mara.marnauza@choir.lv 